\title{
Diaminehalogenoplatinum(II) complex reactions with DMSO
}

Josephsen, Jens

Published in:

Inorganica Chimica Acta

DOI:

10.1016/j.ica.2018.03.039

Publication date:

2018

Document Version

Peer reviewed version

Citation for published version (APA):

Josephsen, J. (2018). Diaminehalogenoplatinum(II) complex reactions with DMSO. Inorganica Chimica Acta, 478, 54-58. https://doi.org/10.1016/j.ica.2018.03.039

\section{General rights}

Copyright and moral rights for the publications made accessible in the public portal are retained by the authors and/or other copyright owners and it is a condition of accessing publications that users recognise and abide by the legal requirements associated with these rights.

- Users may download and print one copy of any publication from the public portal for the purpose of private study or research.

- You may not further distribute the material or use it for any profit-making activity or commercial gain.

- You may freely distribute the URL identifying the publication in the public portal.

Take down policy

If you believe that this document breaches copyright please contact rucforsk@kb.dk providing details, and we will remove access to the work immediately and investigate your claim. 


\section{Diaminehalogenoplatinum(II) complex reactions with DMSO}

Jens Jose

phjens@ruc.dk

Department of Science and Environment, Roskilde University, P.O. Box 260, DK-4000 Roskilde, Denmark

Abstract

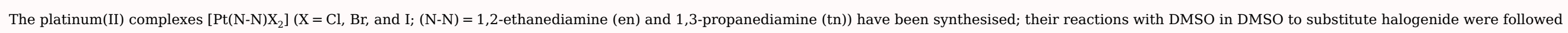

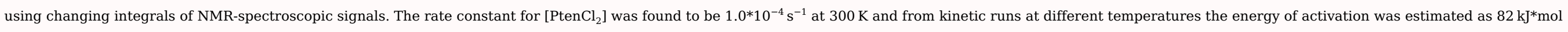
${ }^{-1}$ in this case.

The rate constant depends on the size of halogenide and was found to be forty times larger for [PtenI $\left.{ }_{2}\right]$ than for its dichloro-analogue. In the tn-series reactions were a little faster than in the en-series.

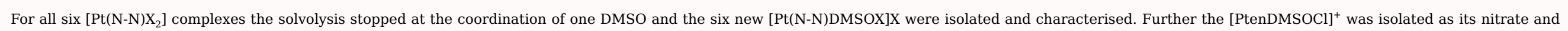
perchlorate. DMSO exchange reactions (in DMSO) of [PtenDMSOX $]^{+}$were found to be slightly slower than the solvolysis reactions, iodide again giving rise to the most labile system.

Ion pair formation in DMSO was found to be modest to almost negligible with a formation constant of $30 \mathrm{M}^{-1}$ in the case of [PtenDMSOCl]Cl as the largest.

Keywords: Platinum(II) diamine complexes; Substitution reaction rates; DMSO

\section{Introduction}

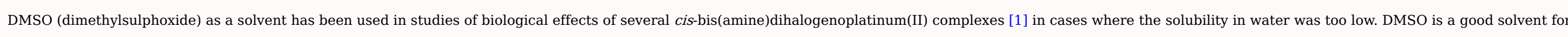
many of these complexes and is also known to act as a ligand and to form well defined coordination compounds with metal ions including platinum(II) [2].

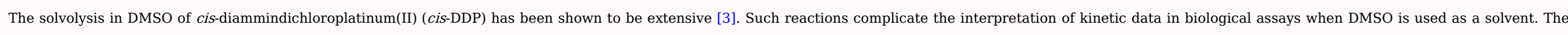
same is true for aqueous solutions in which a cis-trans equilibration also takes place. Indeed, it has been shown that the cytotoxicity is inhibited of currently used platinum drugs dissolved in DMSO [4,5].

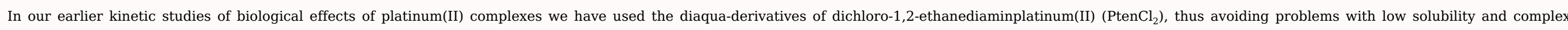
kinetics due to cis-trans equili-bration and the simultaneous hydrolysis in aqueous solution of these complexes [4].

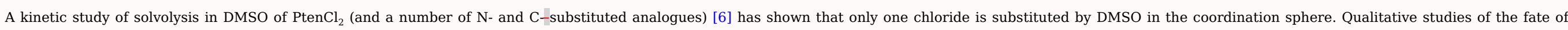

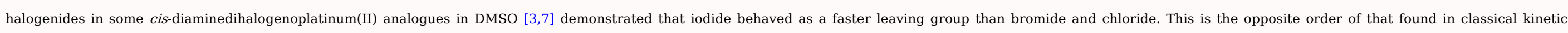

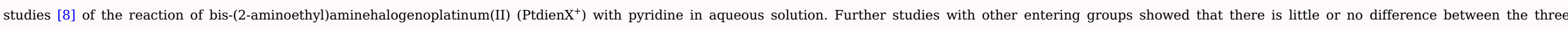

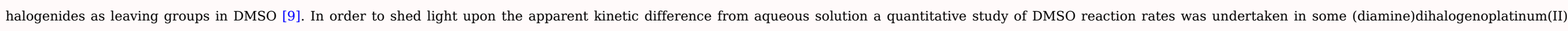
systems varying only the halogenides as the leaving group.

\section{Experimental}

\subsection{Materials}

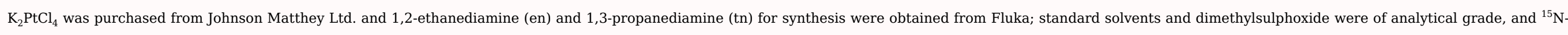
1,2-ethanediamine dihydrochloride $\left(<96 \%{ }^{15} \mathrm{~N}\right)$ was from Prochem (BOC) Ltd. 


\subsection{Syntheses}

\subsubsection{Dichloro-1,2-ethanediamineplatinum(II). [PtenCI $\left.{ }_{2}\right]$}

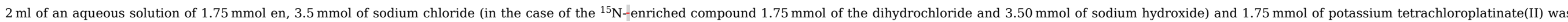

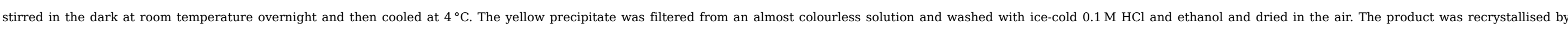

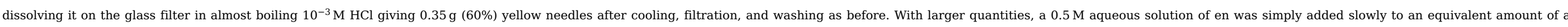
stirred 0.25 M solution of $\mathrm{K}_{2} \mathrm{PtCl}_{4}$ at room temperature in the dark. (Anal. Calc. for $\mathrm{PtC}_{2} \mathrm{H}_{8} \mathrm{~N}_{2} \mathrm{Cl}_{2}$ : $\mathrm{Pt}, 59.82 ; \mathrm{C}, 7.37 ; \mathrm{H}, 2.47 ; \mathrm{N} ; 8.59 ; \mathrm{Cl}, 21.74$. Found: $\mathrm{Pt}$, 59.90; C, 7.22; $\mathrm{H}, 2.40 ; \mathrm{N} ; 8.50 ; \mathrm{Cl}, 21.7 \%$.)

\subsubsection{Dichloro-1,3-propanediamineplatinum(II). [PttnCI $]_{2}$}

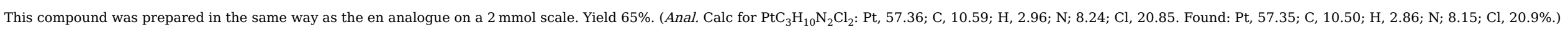

\subsubsection{Dibromo-1,2-ethanediamineplatinum(II). [PtenBr $\left.{ }_{2}\right]$}

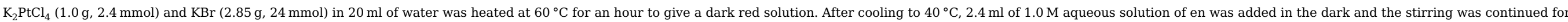

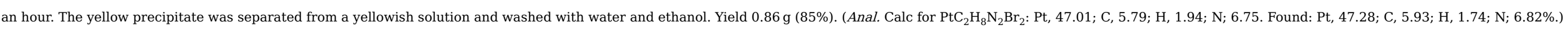

\subsection{4 ${ }^{*}$ Dibromo-1,3-propanediamineplatinum(II). [PttnB $\left.\boldsymbol{r}_{2}\right]$}

This compound was prepared in the same way as the en analogue. Yield 85\%. (Anal. Calc for $\mathrm{PtC}_{3} \mathrm{H}_{10} \mathrm{~N}_{2} \mathrm{Br}_{2}: \mathrm{Pt}, 45.47 ; \mathrm{C}, 8.40 ; \mathrm{H}, 2.35 ; \mathrm{N} ; 6.53$. Found Pt, 45.39; C, 8.48; H, 2.24; N; 6.52\%.)

\subsubsection{Diiodo-1,2-ethanediamineplatinum(II). [PtenI $\left.{ }_{2}\right]$}

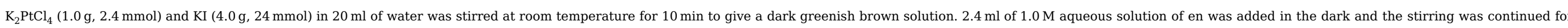

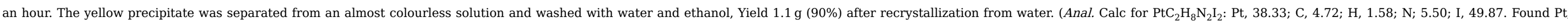
38.40; C, 4.63; H, 1.56; N; 5.50; I, 49.9\%.)

\subsubsection{Diiodo-1,3-propanediamineplatinum(II). [PttnI $\left.I_{2}\right]$}

This compound was prepared in the same way as the en analogue. Yield 90\%.- (Anal. Calc for $\mathrm{PtC}_{3} \mathrm{H}_{10} \mathrm{~N}_{2} \mathrm{I}_{2}$ : Pt, 37.30; C, 6.89; H, 1.93; N; 5.36; I, 48.53. Found Pt, 37.36; C, 6.86; H, 1.86; N; 5.30; I, 48.3\%.)

\subsubsection{Chloro(dimethylsulphoxide)-1,2-ethanediamineplatinum(II) chloride [PtClen(DMSO)]CI}

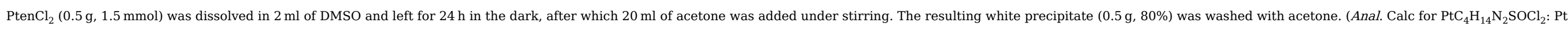
48.26; C, 11.89; H, 3.49; N, 6.93. Found: Pt, 47.9; C, 12.06; H, 3.47; N; 6.87\%.)

\subsubsection{Chloro(dimethylsulphoxide)-1,3-propanediamineplatinum(II) chloride [PtCltn(DMSO)]CI}

This compound was prepared in the same way as its en-analogue with the same yield, $(0.5 \mathrm{~g}, 80 \%)$ and washed with acetone. (Anal. Calc for $\mathrm{PtC}_{5} \mathrm{H}_{16} \mathrm{~N}_{2} \mathrm{SOCl}_{2}$ : C, 14.4; $\mathrm{H}, 3.86 ; \mathrm{N}, 6.70$. Found: C, $14.7 ; \mathrm{H}, 3.85 ; \mathrm{N}, 6.69 \%$.)

\subsection{9 ${ }^{*}$ Bromo(dimethylsulphoxide)-1,2-ethanediamineplatinum(II) bromide [PtBren(DMSO)Br}

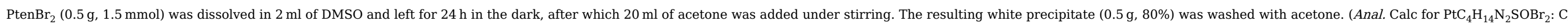
9.74; H, 2.86; N, 5.68. Found: C, 10.0; H, 2.91; N; 5.8\%.)

\subsubsection{0 * Bromo(dimethylsulphoxide)-1,3-propanediamineplatinum(II) bromide [PtBrtn(DMSO)]Br}

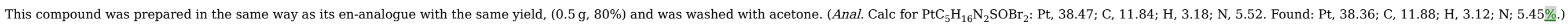

\subsubsection{1 ${ }^{*}$ Iodo(dimethylsulphoxide)-1,2-ethanediamineplatinum(II) iodide [PtIen(DMSO)]I}




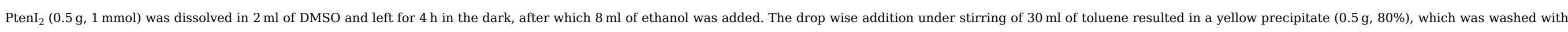
toluene and ethanol. (Anal. Calc for $\mathrm{PtC}_{4} \mathrm{H}_{14} \mathrm{~N}_{2} \mathrm{SOI}_{2}$ : Pt, 33.23; C, 8.18; H, 2.40; N, 4.77. Found: Pt, 33.47; C, 8.21; H, 2.39; N; 4.80\%.)

\subsubsection{2 ${ }^{*}$ Iodo(dimethylsulphoxide)-1,3-propanediamineplatinum(II) iodide [PtItn(DMSO)]I}

This compound was prepared in the same way as its en-analogue with the same yield. (Anal. Calc for $\mathrm{PtC}_{5} \mathrm{H}_{16} \mathrm{~N}_{2} \mathrm{SOI}_{2}$ : $\mathrm{Pt}, 32.45 ; \mathrm{C}, 9.99 ; \mathrm{H}, 2.68 ; \mathrm{N}, 4.66$. Found: Pt, 32.50; C, 10.10; $\mathrm{H}, 2.67$; $\mathrm{N}$; 4.65\%.)

\subsubsection{3 ${ }^{*}$ Chloro(dimethylsulphoxide)-1,2-ethanediamineplatinum(II) nitrate [PtClen(DMSO)]NO}

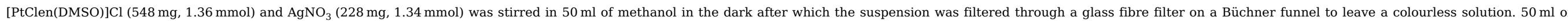
ether was added under stirring and the resulting white precipitate (0.5 g, 90\%) was washed with ether. \%. (Anal. Calc for $\mathrm{PtC}_{4} \mathrm{H}_{14} \mathrm{~N}_{3} \mathrm{SO}{ }_{4} \mathrm{Cl}: \mathrm{Pt}, 45.29 ; \mathrm{C}, 11.15 ; \mathrm{H}, 3.28 ; \mathrm{N}, 9.76$. Found: Pt, 45.2; C, 11.28; H, 3.15; N, 9.63\%.)

\subsubsection{Chloro(dimethylsulphoxide)-1,2-ethanediamineplatinum(II) perchlorate [PtClen(DMSO)]CIO}

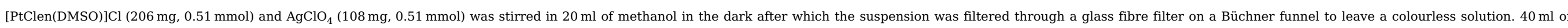
ether was added under stirring and the resulting white precipitate ( $0.5 \mathrm{~g}, 90 \%$ ) was washed with ether. (Anal. Calc for $\mathrm{PtC}_{4} \mathrm{H}_{14} \mathrm{~N}_{2} \mathrm{SO}_{5} \mathrm{Cl} 2$ : C, 10.26; $\mathrm{H}, 3.01 ; \mathrm{N}, 5.98 \%$. Found: C, 10.10; $\mathrm{H}, 3.01 ; \mathrm{N}, 5.93 \%$.)

\subsection{Instrumentation and $\underline{1}$ H NMR data}

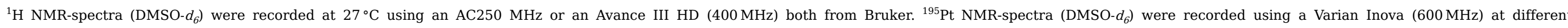
temperatures. -1 H NMR data are given in Table 1.

\section{4-'H NMR data}

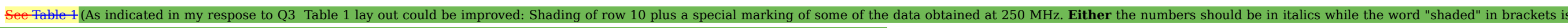
replaced by "in italics" or by a followed by appropriate marking of the relevant data as entered. The last option has been introduced as corrections.)

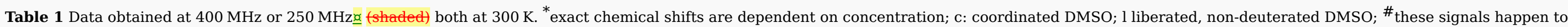

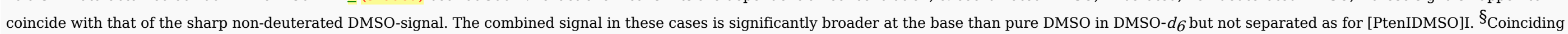
with the DMSO- $d_{5}$ signal from the solvent.

\begin{tabular}{|c|c|c|c|c|}
\hline Numbers in ppm & $\mathrm{CH}_{2}$ & DMSO l & DMSO c & $\mathrm{NH}_{2}$ \\
\hline$\left[\mathrm{PtenCl}_{2}\right]$ & 2.24 & & & 5.31 \\
\hline${ }^{*}[$ PtenClDMSO $] \mathrm{Cl}$ & $2.54^{\#}$ & 2.54 & 3.41 & $6.11 ; 6.48$ \\
\hline${ }^{*}[$ PtenClDMSO $] \mathrm{NO}_{3}$ & $2.54^{\#}$ & 2.54 & 3.40 & $6.04 ; 6.17$ \\
\hline$\left[\right.$ PtenClDMSO]ClO ${ }_{4}$ & $2.54^{\#}$ & 2.54 & 3.39 & $6.02 ; 6.09$ \\
\hline$\left[\mathrm{PtenBr}_{2}\right]$ & $2.21 \underline{\underline{\alpha}}$ & & & $5.33 \underline{\underline{\alpha}}$ \\
\hline${ }^{*}[$ PtenBrDMSO $] \mathrm{Br}$ & $2.54^{\# \underline{\underline{X}}}$ & & & $6.06 ; 6.30 \underline{\underline{\alpha}}$ \\
\hline$\left[\right.$ PtenI $\left._{2}\right]$ & 2.20 & & & 5.28 \\
\hline${ }^{*}$ [PtenIDMSO]I & $2.58(\mathrm{~m}) ; 2.46(\mathrm{~m})$ & 2.54 & 3.60 & $5.94 ; 6.20$ \\
\hline Numbers in ppm & 1- $\mathrm{CH}_{2}$ & 2- $\mathrm{CH}_{2}$ & DMSO c & $\mathrm{NH}_{2}$ \\
\hline$\left[\mathrm{PttnCl}_{2}\right]$ & $2.41 \underline{\underline{\alpha}}$ & $1.54 \underline{\underline{\alpha}}$ & & $4.87 \underline{\underline{\alpha}}$ \\
\hline *[PttnClDMSO]Cl & $2.70 \underline{\underline{\alpha}}$ & $1.77 \underline{\underline{\alpha}}$ & $3.41 \underline{\underline{\alpha}}$ & $5.53 ; 5.64 \underline{\underline{\alpha}}$ \\
\hline
\end{tabular}




\begin{tabular}{|c|c|c|c|c|}
\hline$\left[\mathrm{PttnBr}_{2}\right]$ & $2.48 \underline{\underline{\alpha}}$ & $1.64 \underline{\underline{a}}$ & & $4.92 \underline{\underline{a}}$ \\
\hline${ }^{*}[\mathrm{PttnBrDMSO}] \mathrm{Br}$ & $2.56 ; 2.77 \underline{\underline{\alpha}}$ & $1.79 \underline{\underline{\alpha}}$ & & $5.47 ; 5.60 \underline{\underline{\alpha}}$ \\
\hline$\left[\mathrm{PttnI}_{2}\right]$ & $2.50^{\S}$ & 1.68 & & 4.81 \\
\hline *[PttnIDMSO]I & 2.82 & 1.78 & 3.62 & $5.40 ; 5.53$ \\
\hline
\end{tabular}

\section{Results}

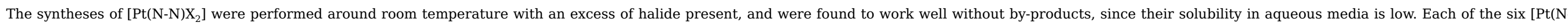

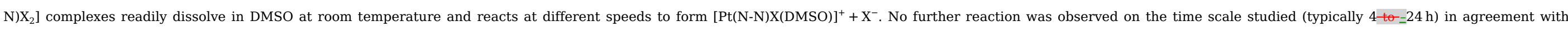
previous results [6].

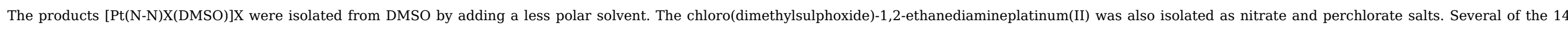
complexes described are new: In the experimental section the complexes without a CAS number has been marked by an asterisk.

\subsection{Kinetics of solvolysis}

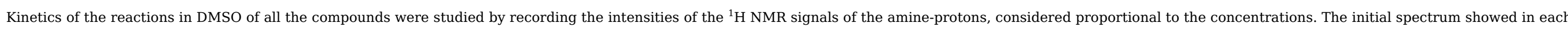

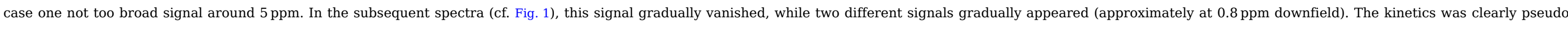

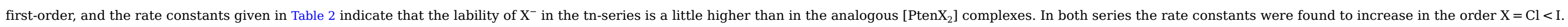

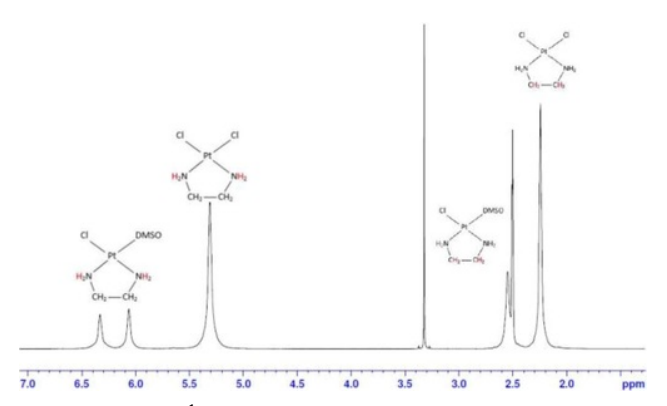

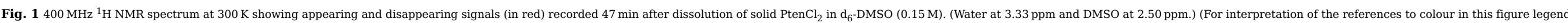
the reader is referred to the web version of this article.)

Table 2 Pseudo first-order rate constants $\mathrm{k}_{1}$ for $\left.\left[\mathrm{Pt}(\mathrm{N}-\mathrm{N}) \mathrm{X}_{2}\right]+\mathrm{DMSO} \rightarrow \mathrm{Pt}(\mathrm{N}-\mathrm{N}) \mathrm{X}(\mathrm{DMSO})\right]^{+}+\mathrm{X}^{-}$.

\begin{tabular}{|c|c|c|}
\hline $\mathrm{k}_{1}\left(\mathrm{~s}^{-1}\right)$ & $\mathrm{N}-\mathrm{N}=\mathrm{en}$ & $\mathrm{N}-\mathrm{N}=\mathrm{tn}$ \\
\hline $\mathrm{Cl}$ & $1.03 \pm 0.02 \cdot 10^{-4}$ & $1.48 \pm 0.02 \cdot 10^{-4}$ \\
\hline $\mathrm{Br}$ & $1.09 \pm 0.02 \cdot 10^{-3}$ & $2.59 \pm 0.03 \cdot 10^{-3}$ \\
\hline I & $4.37 \pm 0.06 \cdot 10^{-3}$ & ${ }^{*} 1.3 \pm 0.1 \cdot 10^{-2}$ \\
\hline
\end{tabular}

${ }^{*}$ Data obtained at $295 \mathrm{~K}$.

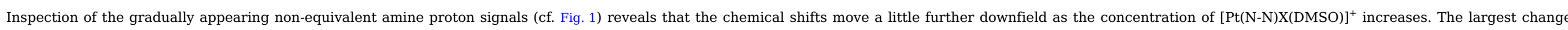

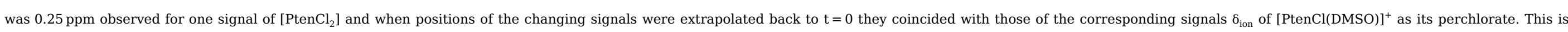




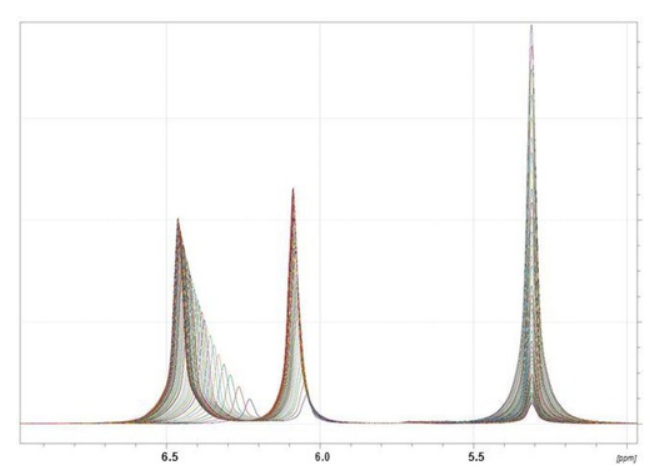

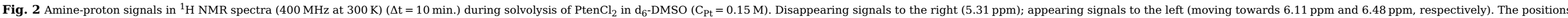

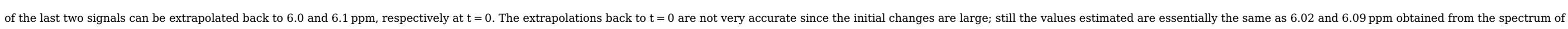
[PtenCl(DMSO) $\mathrm{ClO}_{4}$ in $\mathrm{d}_{6}$-DMSO.

\subsection{Ion pair formation}

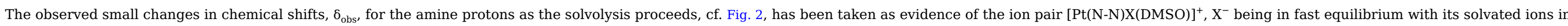

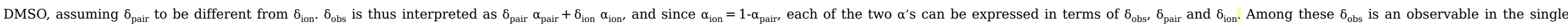
experiment, $\delta_{\text {pair }}$ is unknown, but a constant parameter, and $\delta_{\text {ion }}$ is known from the spectrum of a salt of [Pt(N-N)X(DMSO) $]^{+}$with negligible ion pair formation.

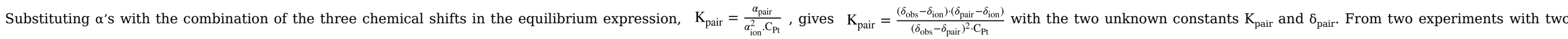
different stoichiometric concentrations, $\mathrm{C}_{\mathrm{Pt}}$, of $\left[\mathrm{Pt}(\mathrm{N}-\mathrm{N}) \mathrm{X}_{2}\right]$ both of these constants can be estimated.

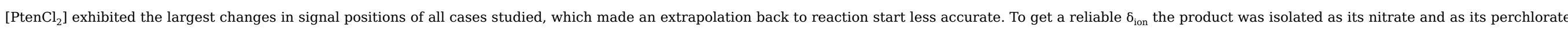

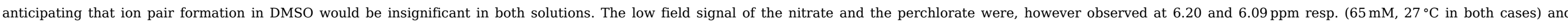

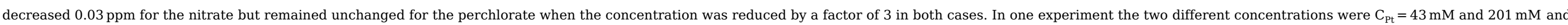

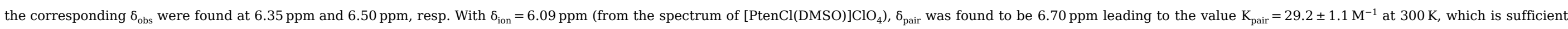

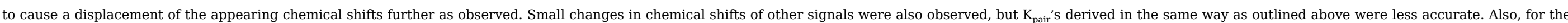

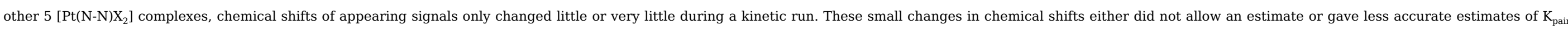
being smaller than $3 \cdot 10^{1} \mathrm{M}^{-1}$ in all cases.

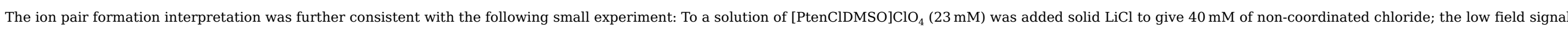
changed to lower fields at a position which agreed within $0.02 \mathrm{ppm}$ with that calculated using $\mathrm{K}_{\mathrm{pair}}=30 \mathrm{M}^{-1}$ at $300 \mathrm{~K}$.

\subsection{Temperature variation}

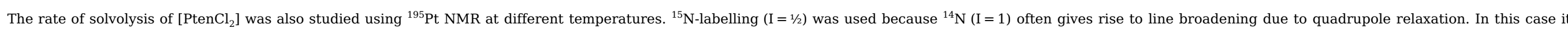

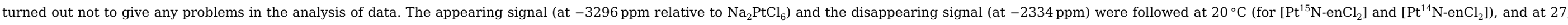

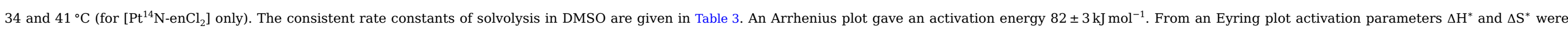
found to be $79 \pm 2 \mathrm{~kJ} \mathrm{~mol}^{-1}$ and $-56 \pm 3 \mathrm{~J} \mathrm{~mol}^{-1} \mathrm{~K}^{-1}$, respectively. The negative entropy of activation found confirms that the substitution mechanism is associative.

Table 3 Pseudo first-order rate constants $\mathrm{k}_{\mathrm{Cl}}$ for $\left[\mathrm{PtenCl}_{2}\right]+\mathrm{DMSO} \rightarrow[\mathrm{Pt}(\mathrm{en}) \mathrm{Cl}(\mathrm{DMSO})]^{+}+\mathrm{Cl}^{-}$at different temperatures, measured using ${ }^{195} \mathrm{Pt} \mathrm{NMR}$ data. 


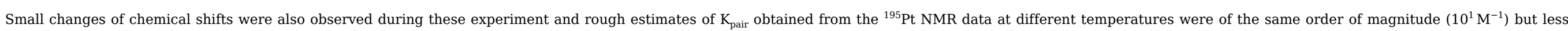
accurate.

\subsection{DMSO exchange rates}

While the solvolysis reactions studied apparently stopped at $[\mathrm{Pt}(\mathrm{N}-\mathrm{N}) \mathrm{X}(\mathrm{DMSO})]^{+}$, DMSO was found to be labile:

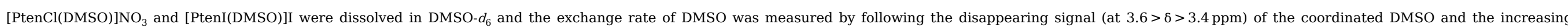
uncoordinated DMSO signal in ${ }^{1} \mathrm{H}$ NMR.

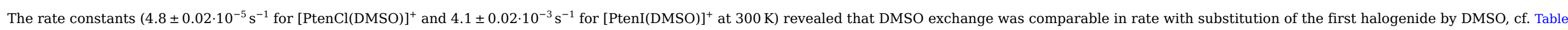
2, and confirmed that iodide had a greater cis-labilising effect than chloride

\section{Discussion}

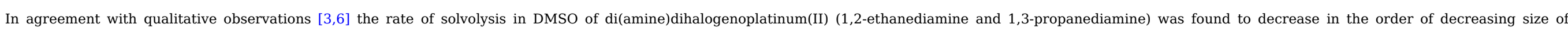
halogenide. The rates were invariably larger in the tn-systems than the analogous en-systems, most so with iodide as the leaving group.

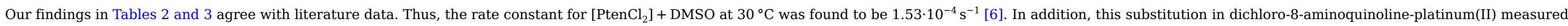

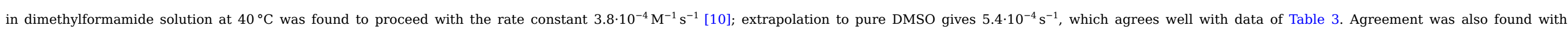

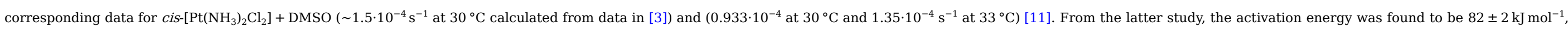
which compares well with our findings in the $\left[\mathrm{PtenCl}_{2}\right]$ system.

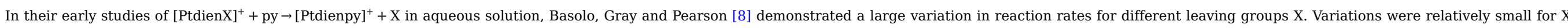

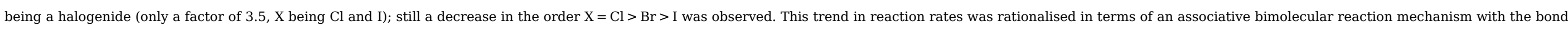

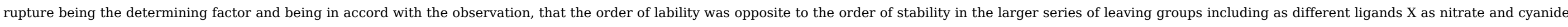
in $[\text { PtdienX }]^{+}$.

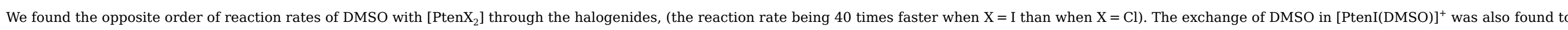

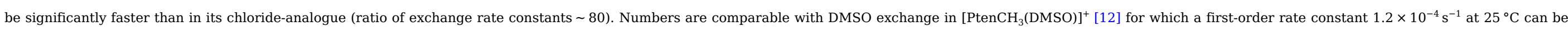
estimated by extrapolating the concentration of DMSO to that in pure DMSO.

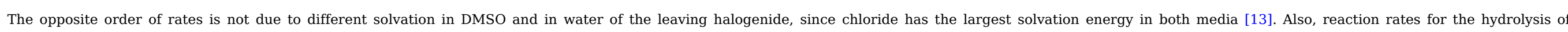

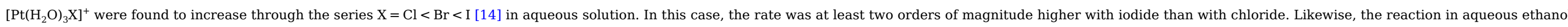
of $[\text { PtdienX }]^{+}[15]$ with dimethyl sulphide followed the same rate pattern (ratio $\sim 4$ ) as reactions with DMSO in DMSO [16], so other unspecified solvent effects are not dominating either.

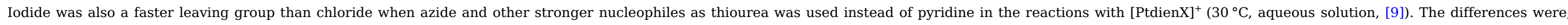

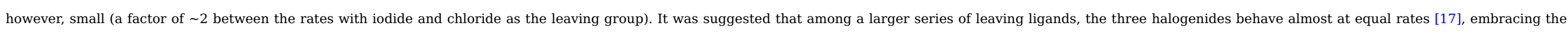
earlier findings with only small differences in rates; this should indicate, that bond breaking is not rate determining.

\section{Conclusion}

Our findings clearly support the view that iodide is generally the fastest leaving group of the three halogenides in most square planar platinum(II) systems mentioned here. 


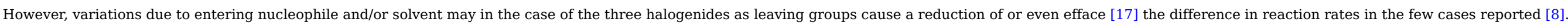

\section{Acknowledgments}

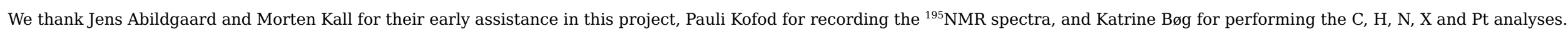

\section{Appendix A. Supplementary data}

Supplementary data associated with this article can be found, in the online version, at https://doi.org/10.1016/j.ica.2018.03.039.

\section{References}

[1] J.M. Pascoe and J.J. Roberts, Biochem. Pharmacol. 23, 1974, 1345.

[2] M. Calligaris, Coord. Chem. Rev. 248, 2004, 351-375.

[3] S.J.S. Kerrison and P.J. Sadler, J.C.S. Chem.Commun. 1977, 861-862.

[4] H.B. Pedersen, J. Josephsen and G. Kerszman, Chem.-Biol. Interact. 54, 1985, 1-8.

[5] M.D. Hall, K.A. Telma, K.-E. Chang, T.D. Lee, J.P. Madigan, J.R. Lloyd, I.S. Goldlust, J.D. Hoeschele and M.M. Gottesman, Cancer Res. 74, 2014, 3913-3922.

[6] F.P. Fanizzi, F.P. Intini, L. Maresca, G. Natile and G. Uccello-Barretta, Inorg. Chem. 29, 1990, 29-33.

[7] S.J.S. Kerrison and P.J. Sadler, Inorg. Chim. Acta 104, 1985, 197-201.

[8] F. Basolo, H.B. Gray and R.G. Pearson, J. Am. Chem. Soc. 82, 1960, 4200-4203.

[9] U. Belluco, R. Ettore, F. Basolo, R.G. Pearson and A. Turco, Inorg. Chem. 5, 1966, 591-593.

[10] M. Ray, S. Bhattacharya and P. Banerjee, J. Indian. Chem. Soc. 76, 1999, 121-124.

[11] W.I. Sundquist, K.J. Ahmed, L.S. Hollis and S.J. Lippard, Inorg. Chem. 26, 1987, 1524-1528.

[12] R. Romeo, L.M. Scolaro, N. Nastasi and G. Arena, Inorg. Chem. 35, 1996, 5087-5096.

[13] F. Rodewald, K. Mahendran, J.L. Bear and R. Fuchs, J. Am. Chem. Soc. 90, 1968, 6698-6700.

[14] L.I. Elding and L.-F. Olsson, Inorg. Chim. Acta 117, 1986, 9-16.

[15] S.C. Chan and S.B. Tong, Inorg. Chim. Acta 5, 1971, 634-636.

[16] J. Josephsen Unpublished results.

[17] A. Peloso, Coord. Chem. Rev. 10, 1973, 123.

\section{Appendix A. Supplementary data}

Multimedia Component 1

Supplementary data 1

Graphical abstract

Kinetics of solvolysis of $\left[\mathrm{PtenCl}_{2}\right]$ followed by ${ }^{1} \mathrm{H}$ NMR. Signals of amine protons signals in $\left[\mathrm{PtenCl}_{2}\right]$ (right-staying at $5.31 \mathrm{ppm}$ ) and $[\mathrm{PtenDMSOCl}]^{+}$(left changing due to ion pair formation). 


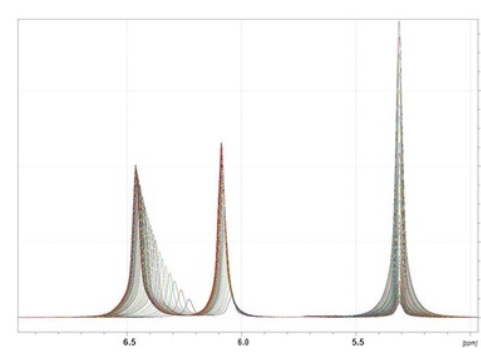

Highlights

- Kinetics of substitution in [PtdiamineX ${ }_{2}$ ] in DMSO by ${ }^{1} \mathrm{H}$ and ${ }^{195} \mathrm{Pt}$ NMR.

- Ion pair formation in DMSO of [PtdiamineDMSOX $]^{+}, \mathrm{X}^{-}$

- 7 new [PtdiamineDMSOX]+ salts isolated and characterised.

\section{Queries and Answers}

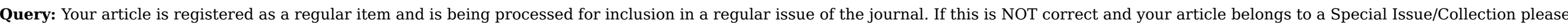
contact v.david@elsevier.com immediately prior to returning your corrections.

Answer: Yes

Query: The author names have been tagged as given names and surnames (surnames are highlighted in teal color). Please confirm if they have been identified correctly. Answer: Yes

Query: Please check the Section 2.4 and correct if necessary.

Answer: Row 10 should be shaded like Row 1 and the 5 entries centered.

Query: Please note that Table 1. was not cited in the text. Please check that the citation suggested by the copyeditor is in the appropriate place, and correct if necessary. Answer: Another solution to this "problem" is provided in the response to Q3 